\title{
The Activities of E-Learning in English Foreign Language Classroom:
}

\author{
Study in a Private University
}

\author{
Ikbal Opus Nurullah*, Asep Suryana \\ School of Postgraduate, Educational Administration \\ Universitas Pendidikan Indonesia \\ Bandung, Indonesia \\ *ikbalopus@upi.edu, doef@upi.edu
}

\begin{abstract}
E-learning using Edmodo become a topic discussion in this study which aimed to find out the students' activities during the learning process, and also discovered the benefits and limitations that faced by them. This study was conducted under qualitative approach by using case study method, and analysed using coding adapted from Saldana by using constant comparative method. The research of this study was held on the second semester, at the third grade of $A, B$, and $C$ class of English Education Department on Universitas Gunung Jati in Cirebon. The results showed that the implementation of elearning was quite different with the traditional method. Elearning method using application-platform as main supporter in learning process, which provided some benefits and limitations. Then, the second is related to benefits and limitations of the elearning implementation which is still very contrast. On the other hand, e-learning provides effectiveness both for the lecturer and students. However, when discipline is not accompanied by facilities and motivation from users, then the level of work tasks through e-learning still have to be encouraged by the educators.
\end{abstract}

Keywords-e-learning activity, Edmodo, English foreign language classroom

\section{INTRODUCTION}

English Education is a place for the cultivation of values in learning English through instruction, guidance, practice, and presentation with consciously and responsibly in the framework of learning. Currently, the modern era is a lot of people who use technology in various fields and usually the individual cannot be separated in the use of technology, such as the use of online media in the field of Education. Various technology-supported lessons are now being used to enhance students' achievements and engagement for educational purposes [1].

The electronic learning (e-learning) is the use of technology in learning which comprises a wide range of application and process design to deliver instruction through electronic means. Considering the fact that traditional classroom does not provide opportunities for students to explore other sources outside, utilizing the technology as a bridge to the wider knowledge. E- learning offers the ability to share material in all kinds of formats such as videos, slideshows, word documents and PDFs [2].

E-learning is mainly to alter a traditional and conservative school system into effective and innovative area for learning which combine the theoretical and modern parts. A tool that allow the lecturer into online educational curriculum. From those problem and assumption makes the writer interest in observing the implementation of electronic learning (elearning) activities and investigating the benefit on students' self-development in English Educational Department of Swadaya Gunung Jati University. Thus, the aim of this research was as follows:

- To find out the implementation of e-learning activities for the students in English Educational Department of Swadaya Gunung Jati University.

- To find out the benefit and limitation for the students from e-learning activities.

The researcher only involved for third grade students in A C class in English Education Department of Faculty Teaching and Educational Sciences of Swadaya Gunung Jati University who use Edmodo as the main respondents.

\section{LITERATURE REVIEW}

\section{A. E-learning Education}

E-Learning is a general term used to refer to a form of learning in which the instructor and student are separated by space or time where the gap between the two is bridged through the use of online technologies [3]. According to the citation above, e-learning enables people to better prepare especially in teaching-learning process both teacher and students, also the users can access the learning everywhere from long distance or nearby. It can efficiency the time in everything that can be done in the class. 
E-Learning must be connected with the internet and helped by electronic resource as the component of E-Learning form when teaching can be based in or out of the classroom. Also, the E-Learning can be termed as a network-enabled transfer of skill and knowledge, and the delivery of education was made to some huge recipients at the same times.

\section{B. E-learning Application Platform}

An e-learning platform is a software application that integrates different management tools, communication, evaluation, monitoring, etc., with the aim of providing technological support to teachers and students to optimize the various phases of the teaching-learning process [3]. An application platform that suitable with what the user needed to make the teacher and students easier, giving the instruction and also doing the assignment.

There are certain application-platforms which are used frequently by the students in English Educational Department of Unswagati, as the Learning Management System (LMS) to implementing e-learning. These application platforms are:

- Edmodo: Edmodo is a social network for learning-based Learning Management System (LMS) [4]. Edmodo gives facilities to teacher and students even for parents in teaching and learning process with teacher as tutor, students as participant, and parent as a supervisor for their children's progress.

- Schoology: Schoology is one of the social Web-based LMS that offers the same learning as in a free class and easy to use like social media Facebook [5]. That statement explains Schoology had a feature similar with Facebook which make fun and interesting when the user uses it.

1) Edmodo work system: Edmodo learning media can be accessed via mobile and it is available for Android and iPhone smartphones. The easier for the education to learn and hopefully with this Edmodo can equate the smoothness of educational learning method in Indonesia. Edmodo enables students to connect with each other closely and contributes to developing a strong classroom community [6].

In this era, all students of any type will tend to like technology and are familiar with it. In security system, Edmodo provides special codes for schools and classes. These codes are given to the students and are required to join the group. Edmodo is a highly user-friendly application for educational purposes, and its access is limited to students and teachers who are registered [7]. The latest, Edmodo is providing security services by implementing SQL injection protection to prevent unauthorized access to website and database resources.

2) E-learning for EFL classroom: Learn another language provides memory access to a position other than one's own, increase the power to see connections across content areas, and promotes an interdisciplinary perspective while gaining intercultural understanding. In increase, technology plays a significant function in the educational arena; therefore, it is essential to conduct inquiry into the quality of English language teaching at this point, particularly in the use of technological tools to be used in the classroom

Information and Communication Technologies (ICTs) are very important in the field of education because they can change the environment of the classroom and allow the subject matter to become more accessible for the learner [8]. It is clear that there is a changing understanding today of the mission of teaching EFL. We have to admit that language learning in general has been changing so drastically in recent years [9]. Language educators have become quite convinced that the way learners are eruditeness the words at nowadays is totally different from the way that they themselves were learning it in the past.

If we go back to the past, various educational institutions used to provide classes in words laboratories that enabled scholar to implement engineering science devices where teacher monitored students' interaction. Currently, the use of technology in the classroom has opened up new possibilities for language education through the web generations that positively contribute to the teaching-learning process. The positive outcomes of the tools listed above can only be possible with appropriate methodology and teachers' management applied in the classroom.

The use of technology in education, commonly defined as e-learning, has become a standard component in many materials. Technology applications are not restricted to the classroom - they are also placing some classroom sessions with virtual sessions or fully replacing classroom courses with online courses.

\section{METHODOLOGY}

This research used qualitative case study research. Yin defines the case study research method "as an empirical inquiry that investigates a contemporary phenomenon within its reallife context; when the boundaries between phenomenon and context are not clearly evident; and in which multiple sources of evidence are used" [10]. On the other hand, Zainal stated that researchers can adopt either a single-case or multiple-case design depending on the issue in question [10]. However, this research focus on detail information about how the implementation of e-learning activity and the benefit that students get from e-learning activity.

The participants of this research are the third graders of English Educational Department of Unswagati who were taught with Edmodo as well as main subject were third A, B, and $\mathrm{C}$ class which consist of 38 students.

The data were collected using observation sheet, questionnaire, interview and documentary reviews. Overall analyses were systematically conducted by the following steps: processing and analysing the selected data that had been collected and summarizing the findings and creating 
conclusion. According to the method in this research, the data were analysed using constant comparative method. Several steps of constant comparative method which the most appropriate analysis method for this study as in figure 1[11].

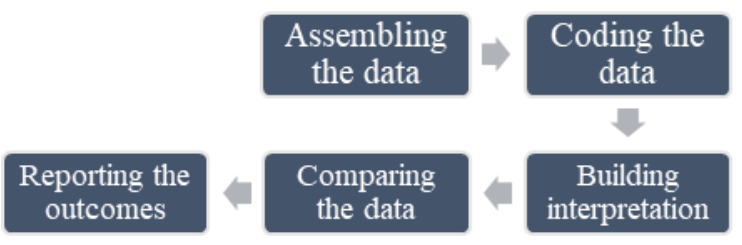

Fig. 1. Process of data analysis.

\section{FINDINGS AND DISCUSSION}

\section{A. The Implementation of E-Learning in EFL Learners' Class}

Education cannot be out of date especially in this globalization era, there are so many media and the other things which use the internet to develop their qualities. In this research, the writer focused on the use of Edmodo for EFL learners' learning process. Edmodo application-platform used during the learning process in one semester to facilitate the lecturer and students' learning activities.

Based on the results from the research that had been done with observation, interview, and documentation in the third grade of A, B, and C classes of English Education Department who were used electronic learning with Edmodo, all of the materials, practices, and final assignment were carry out and being posted via Edmodo. This concept gives the students a flexibility to work on the task given by the lecturer anytime, not depend on the class situation which not all of the students feel comfortable with. Moreover, by using electronic learning the students become more flexible in collecting the tasks, which means they might do or collect the tasks not only around the campus, but they can give the task anywhere even there is still a deadline for students to submit the task that lecturer gave via Edmodo.

Through the implementation of e-learning using Edmodo, students are given the discretion to discuss both directly and indirectly through Edmodo, then e-learning can follow the habit such as social media and surf the internet to avoid the students get bored with the learning activities. The implementation of e-learning activity in English teaching and learning of EFL learners are explained below:

\section{B. Warming Up}

At the beginning of the meeting, the lecturer gave an introduction for each class of the course using e-learning through Edmodo application-platform which contains the objectives which should be achieved in the course, what activities will be conducted during the semester, and what task will be given at the end of the semester. In addition, the lecturer explained how to use Edmodo as a medium of instruction. Motivation has been given to the students in order to make them not to give up in developing and learning in this course. Afterward, there was a test held at the beginning of the meeting in the form of a written test that requires students to create a simple essay in one paragraph and deposited through the application Edmodo with a predetermined time.

1) Implementing: Observation of the research showed that most of the learning process takes place in Edmodo and the lessons less intensive in the classroom. Usually when the lecturer in the class, the lecturer provided and explained the kind of task that should completed by students with explanations regarding the material of the assignment given to the students. Students are given the discretion to discuss each other when after the lecturer completed the explanation and invites the students to ask questions. Every task that have been described in the classroom is always re-published either command, guide, or the example of the task. Even before the final exam, lecturer have given the final assignment to the students to be completed with a grace period of a week before the day has listed. The lecturer always announced those tasks via Edmodo. It has been seen that time becomes a major factor in e-learning method using Edmodo, because the discipline aspect becomes sustainability support that occurs in those classes when apply the e-learning method using Edmodo application-platform.

2) Evaluation: The lecturer gave and explained the tasks in the classroom and repost via Edmodo application-platform, the lecturer gave a treatment when after the deadline over and the lecturer checked the student's work, the lecturer gives feedback on their task and not reluctant to comment on students who asked and comment on the student's work through Edmodo application-platform. At the end of the meeting, the lecturer corrects the results of student's work during the final examination of the grades included in the assessment during the course of the semester. There has been no response to Edmodo's used as an evaluation material for the next implementation of e-learning.

\section{The Benefits and Limitations of E-Learning}

Here are the data analysis from students' class A, B, and C questionnaire results related to the benefits and difficulties of elearning activity:

\section{1) Benefit}

TABLE I. Students' Perspective ABout Benefits of E-LEARning.

\begin{tabular}{|l|l|}
\hline \multicolumn{2}{|c|}{ What are benefit that you get from e-learning? Please explain! } \\
\hline \multicolumn{2}{|c|}{ Rmount } \\
\hline Easy access for learning & 27 \\
\hline Developing teaching materials & 9 \\
\hline Saving time & 5 \\
\hline Discipline & 3 \\
\hline Critical thinking & 1 \\
\hline Motivating the learning process & 1 \\
\hline Managing time & 1 \\
\hline
\end{tabular}

From the table 1 above, it can be said that e-learning gives effectiveness for the students, when accessing the materials, 
developing the materials, time, and also students' individuals. The easiness when accessing the materials proved by the terms which the lecturer always gives a flexibility to students because they may search any information and knowledge via online everywhere.

\section{2) Difficulties}

TABLE II. STUDENTS’ DIFFICULTIES IN USING E-LEARNING.

\begin{tabular}{|l|l|}
\hline $\begin{array}{l}\text { What are difficulties that you feel from e-learning process? } \\
\text { Please explain! }\end{array}$ \\
\hline \multicolumn{1}{|c|}{ Response } & \multicolumn{1}{c|}{ Amount } \\
\hline Low of facilities & 19 \\
\hline Misunderstanding & 16 \\
\hline Error on the platform & 6 \\
\hline Hard to operating platform & 5 \\
\hline Low motivation & 2 \\
\hline Poor of information & 1 \\
\hline
\end{tabular}

Some of the respondents agree that the university should meet the facilities in advance of the implementation of elearning so that the process can run well. The process of elearning can also lead to misunderstanding of instruction given by the teacher to the student and vice versa, so that the delay in solving the task becomes a problem experienced by the students. The researcher can be concluded some benefits and limitations of e-learning activity as follow:

- Learning access: The used of Edmodo applicationplatform has made it easier for students to fulfil the task given by lecturer so as not to be limited only in the classroom, but they may complete and submitted the assignment anywhere. As well as from its use, Edmodo is more environmentally friendly where Edmodo users can save on paper (paperless) commonly used to collect assignment. In conducting the teaching learning process, those activities related to the assignments can be done from different places through the comment feature, video streaming, and the data source from internet.

- Time management: Saving the time. Implementation of e-learning method can save time which is usually limited because they have to search and dissect the book first, but with the existence of digital search engine activities more accelerate with the search of the data resource. The students can get any information needed quickly through the internet and they can directly submit the assignment via Edmodo platform. The existence of deadline system provided by Edmodo can form the character of students who are disciplined, because when the time is over students cannot longer submit their work in Edmodo. So that the system makes the students more disciplined to immediately and prepare to submit their duties

- Learning effectively: Edmodo's appearance its look like Facebook that can make it easier for most students to operate features in Edmodo because they already familiar with this kind of display and features. Here is how the Edmodo looks like:

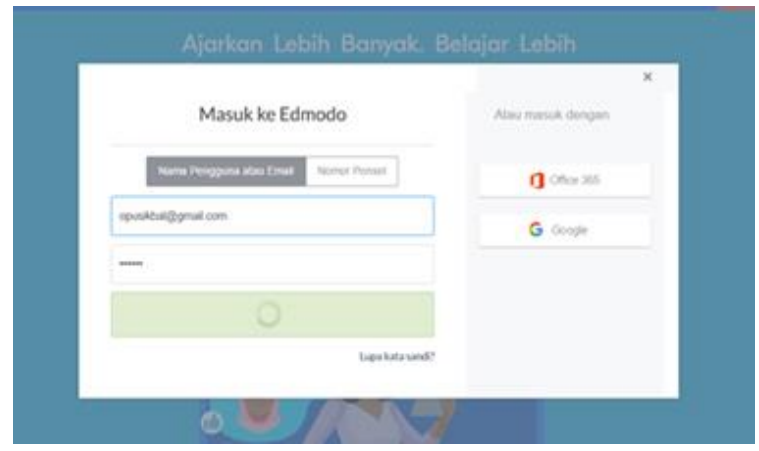

Fig. 2. Edmodo's log in page.

The picture above illustrated about the homepage of Edmodo application-platform. The students can effectively learn about the materials and tasks given by the lecturer through features facilitated by this application-platform. It can be seen clearly that elearning activity give unlimited access for students in conducting their learning. There is also a comment section, which is useful for student who wants to know more about the task given by the lecturer, or even for conduct any discussion for several issues with their classmates. Moreover, by using e-learning students are encouraged to take advantage of other application such as Google Search engine to increase their knowledge and data from the tasks assigned by lecturer.

- Low motivation: Related to the result that the researcher got, there were several students who still not familiar with e-learning method. It conduces students' incomprehension when running some features in Edmodo application-platform. Some of them were confused with the functions of Edmodo, and they were feeling ashamed to asked about this kind of difficulties to their friend or to the lecturer. A lack of desire when doing the e-learning activity was clearly visible. Since the lecturer gives comments on what students posted and gives several assignments via Edmodo, the students were frequently just read and did not give any comments towards the post which the lecturer conveyed. It is because with the open-format of Edmodo, all of the students on the group may read to what they post or inform. So that, they feel ashamed and fear of mistakes which make them hesitate and there was no motivation of them to post something on Edmodo if there is no instruction from the lecturer.

- Challenge in implementing e-learning: The main challenge is the facilities at the classroom, some of the classroom still not ready yet for the e-learning method. It is because not only one feature or facilities which is need for this learning activity. An example of facilities 
that are considered not adequate according to students is $\mathrm{Wi}-\mathrm{Fi}$ access that makes students being connected to the internet or the most important aspect in the implementation of e-learning method is the need of internet access in the campus which is still not sufficient. Then the campus' computer, although many of the students have smartphone technology or personal laptop, sometimes there are some students who say did not have adequate tools to surf the internet. So, that the required facilities from English Education Department is needed. That statement supported by the data analysis from questionnaire below:

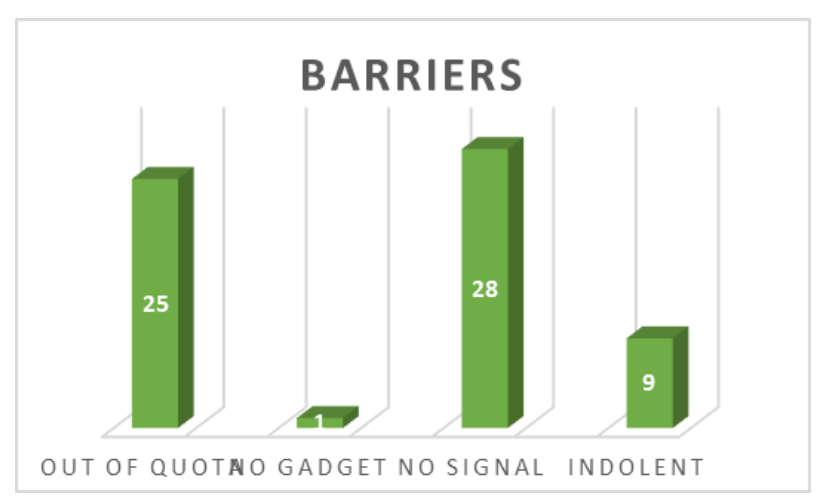

Fig. 3. Students barriers.

The second challenge which being judged by the students to have an effect in the implementation of elearning is about the instruction. Some of them can understand well related to what the lecturer delivers via Edmodo, but some of the rest cannot understand or confused with the instruction. However, not all of the students can discuss about the materials and tasks well, there were some students who are still less in socialize with their classmate and unwilling to ask the lecturer about the instruction. They feel shame to expressing their opinion or their ideas directly. This situation will make them difficult during the learning process. The last challenge discovered was the problem with Edmodo application. A lot of the students complained that Edmodo was not stable to use, because sometimes its occur an error in the application. They said that there was a bug which discourage them when submitting the assignment via Edmodo and caused their assignment were undeliverable. There is still a lot of balance that needs to be fixed on e-learning method using Edmodo in English Education Department, both in terms of facility, students, and also the lecturer. Thus, it is needs to be more attention in order to create a new and adequate learning culture.

\section{Discussion}

Based on the findings above, e-learning is a method that used by lecturer in English Education Department of Swadaya Gunung Jati University. It provides opportunities to students learning by effective experience in students learning process. Related to the Misdi in National Workshop on Educational ICT that Living in the 21st Century, teachers are demanded to master Information and Communication Technology to make teaching easier [12].

To follow the globalization both teacher or students must be up to date in teaching and learning process. In this case, students are given opportunities to take more advantages of technology with e-learning method. Obviously, the e-learning method is different with traditional method in teaching learning process. The use of application-platform that became the introduction of the learning process who was needed as revealed by Canals and Garcia "An e-learning platform is a software application that integrates different management tools, communication, evaluation, monitoring, etc., with the aim of providing technological support to teachers and students to optimize the various phases of the teaching-learning process" [3]. Thus, aspect becomes a contracting contrast of both elearning and traditional method.

In teaching learning process at the third class of $\mathrm{A}, \mathrm{B}$, and $\mathrm{C}$ using Edmodo application-platform as a conductor of the lessons. Edmodo looks similar to Facebook [13], but with the different feature and conditions. As in face-to-face learning, Edmodo also supports the "team teaching" learning model. Teachers are easily invited other teachers to become the coteachers. Another feature of Edmodo is applied to parents, they got a code which is same as the code given to their children. Parents have access rights to monitor their children's progress and may also discuss with teachers and also student to student. The learning process more takes place in Edmodo and the lessons in the classroom is less intensive. Usually when the lecturer taught in the classroom, the lecturer provided and explained what task should be completed by students with explanations regarding the material of the assignment given to the students.

But there are many more things from the use of Edmodo applications, such as the use of time is relatively more efficient in finding data, operating Edmodo anywhere and anytime so the students do not have to go or stay in campus just to collecting their assignment, then when the work will even more tasks with search engine facility as a supporter of data needs for the task.

Nevertheless, e-learning using Edmodo applicationplatform still has many obstacles that affect the continuity of its learning. These barriers come from campus facilities and also the students. Other obstacles come from the Edmodo app itself, where Edmodo apps are inaccessible, fail to send files, and there are still many bugs inside. From the results of these studies with the habit of entrenched the researchers believe that the creation of a balanced or good e-learning activity.

\section{CONCLUSION}

The conclusions are based from the findings. Meanwhile, the suggestions are intended to educational field and for the further research. The writer draws some conclusions after 
analysing the whole findings of the research, as follows: (1) the implementation of e-learning method was often carried out outside the class through Edmodo. Where e-learning method using Edmodo application-platform as main supporter in learning process, which provided some benefits and limitations; (2) benefit and limitation of the use of e-learning have a tendency for each aspect. On the one hand, e-learning provides effectiveness for both lecturer and students. However, discipline when not accompanied by facilities and motivation from users, then the level of work tasks through e-learning still must be encouraged by the educators.

Teacher can use e-learning concept as an innovative and facilitate the regulation of learning that is usually pegged in the classroom. Moreover, it also can give new perspective for students from educators to use technology wisely.

\section{ACKNOWLEDGMENT}

I am especially grateful for Dr. Asep Suryana, M. Pd and Dr. Misdi, M. Pd for their advice on my research. Because of them I can barely finish my research about E-learning.

I am deeply indebted to my supervisor, Professor Dr. Hj. Aan Komariah, M.Pd. Head of Department of Education Administration, for warm support, inspiration and thoughtful guidance.

Special thanks to all the committee of ICREAM 2020 and the Editor for my research.

Finally, I am indebted to my parents, my friends for their continuous support and encouragement for my pursuit.

\section{REFERENCES}

[1] P. Shrestha, Book review: Innovations in Learning Technologies for English Language Teaching, G. Motteram (Ed.). British Council, London 2013. System, 42, 474-475, 2014.

[2] Epignosis LLC, Concepts, trends, applications, V 1.1, Epignosis LLC. All rights reserved, San Francisco, 2014. www.efrontlearning.net.

[3] H.C. Guenaneche, Communication Software Laboratory, 2008

[4] D. Kristiani, "E-Learning dengan Aplikasi Edmodo di Sekolah Menengah Kejuruan,” Prosiding Seminar Nasional Multi Disiplin Ilmu, pp. 36-45, 2016.

[5] S.F. Tsaniyah, H.D. Ayu and H.Y. Pratiwi, "Pengaruh Model Blended Learning menggunakan Schoology Terhadap Prestasi Belajar ditinjau Dari Kemandirian Belajar Siswa,” J. Terap. Sains Teknol. 1, pp. 71-77, 2019

[6] A.C. Denmark, An online learning platform for English as a second language for young Deaf Indian sign language users: Usage patterns and user engagement (Doctoral dissertation, University of Central Lancashire), 2012.

[7] M.U. Hoesny, H. Cahyani and I.N. Aziz, "The Use Of Edmodo In Esp Classroom: A Study On Students'perception And Classroom Activities," Journal of Languages and Language Teaching, vol. 8, no. 3, pp. 237$250,2020$.

[8] L. Solano, P. Cabrera, E. Ulehlova and V. Espinoza, "Exploring the Use of Educational Technology in EFL Teaching: A Case Study of Primary Education in the South Region of Ecuador," Teaching English with technology, vol. 17, no. 2, pp. 77-86, 2017.

[9] M.M. Abdallah, Teaching English as a Foreign Language from a New Literacy Perspective. Assiut University College of Education, Egypt, 2011

[10] M. Bolder-Boos, "Der Krieg und die Liebe-Untersuchungen zur römischen Venus," Klio, vol. 97, no. 1, pp. 81-134, 2015.

[11] G. Crookes, Resources for incorporating action research as critique into applied linguistics graduate education, 2005.

[12] Misdi, National Workshop on Educational ICT, Inst. Islam. Stud. Cirebon. (n.d.). https://misdi.weebly.com/

[13] A.N. Majid, "The use of information technology in teaching English: An attempt to develop student-centered learning at Telkom Polytechnic," Konferensi Nasional ICT-M Politeknik Telkom, 2011. 